\title{
Split Infinitives in Early Middle English
}

\author{
Elly van Gelderen \\ Arizona State University \\ ellyvangelderen@asu.edu
}

\begin{abstract}
The split infinitive is one of seven syntactic properties that English is said to share with Old Norse, and I will show that, on the basis of the area and date of its first occurrence, Norse origin is unlikely.
\end{abstract}

\section{Keywords}

historical syntax - language contact - history of English - Germanic

On the basis of a number of similarities between Middle English and Old Norse, Emonds and Faarlund (2014; this issue) argue that the former descends from the latter. They mention the Danelaw, i.e. the Northeast-Midlands, as having been the area of most contact between the two language groups, but do not systematically connect the (syntactic) similarities they note to their earliest occurrence in that area. The split infinitive is one of seven syntactic properties English is said to share with Old Norse and I will show that, on the basis of the area and date of its first occurrence, Norse origin is unlikely.

Callaway (1913: 148 $8^{1}$ ) notes that the first split infinitive in English is (1), where the object helpe splits for and to hauene. This would have been very good news for the 'Middle English is Old Norse' hypothesis because (1) is from the last part of a Chronicle from the Danelaw area. However, because for is a complementizer and to immediately precedes the verb, (1) is not what is usually meant by a split infinitive and it doesn't resemble the single Norse infinitive marker at.

1 Noted in Visser (1972: 1035). 
(1) oc se kyng hit dide ... for helpe to hauene togcenes his neue Willelm. 'but the king did it ... in order to have help against his nephew William.' (Peterborough Chronicle, 1127.10)

Emonds and Faarlund (2014: 97-107; this issue) say that the Old Norse infinitive marker at is a complementizer, and its complementizer status is what allows split infinitives in that language. Once v-to-T movement disappears in Old Norse, there are even more split infinitives, which therefore also increase in the English influenced by Norse. Unfortunately, the Middle English examples they give are not all from the Early Middle English period and, what is more problematical, the early ones are from dialect areas outside the Danelaw, namely the West Midlands. The split infinitives provided (2014: 106) are from Layamon's Brut, 13th-century West Midlands, Sir Gawain, 14th-century West Midlands, Purvey's Romans, late 14th century but close to the Danelaw, and

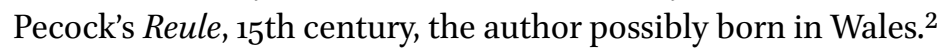

So although there is no evidence in Emonds and Faarlund (2014; this issue) linking the area of the Danelaw with the earliest occurrences of the split infinitive, their work will stimulate much further research. A few new questions are (a) what prompts the appearance of the complementizer/infinitive marker at in (2), a Northern version of this early 14 th-century text, and (b) why does the split infinitive occur in many versions of this text, as (3) shows?

(2) Yee send a man at it receiue

'You are sending a man to receive it.' (Cursor Mundi, Cotton 7746)

(3) a. He sal pe send Angels for to pe defend

b. ... angels for to pe defende

c. ... angelis forto pe defend

'He shall send angels to defend you.' (Cursor Mundi 12965, Cotton, Fairfax, Göttingen manuscripts)

As for the Peterborough Chronicle, if Norse influence is really important in that area at the relevant time, the most notable differences between the earlier (before 1121; Emonds and Faarlund, this issue) and later parts need to be accounted for. The changes after 1121 involve the introduction of definite articles, the finite complementizers till and for, and the new pronoun she, and of course the demise of the ge-prefix on participles. Two of these changes, the

2 See van der Gaaf (1933) for most of these examples, (3) below, and many more. 
introduction of til and the loss of ge- on iafen, are exemplified in (4), and these are very likely due to influence from Norse.

\section{(4) til hi iafen up here castles \\ 'till they gave up their castles' (Peterborough Chronicle, 1137)}

So far, I have only looked at split infinitives and conclude that there is not a good match between area of first occurrence and Norse influence. As for the true Accusative-with-infinitive, which is "absolutely absent from Old English" (2014: $76-78$; this issue), I think that Emonds and Faarlund make a case that Old Norse was as plausible an external influence as Latin. Again, their sources are not linked to the early Danelaw area. My own hypothesis is that the rise of the Accusative-with-infinitive is linked to that of the split infinitive through an internal change: $t o$ is seen as a $\mathrm{T}$ (see van Gelderen, 1993).

In conclusion, it is always good to hear about a new angle. It may lead to more work on the Peterborough Chronicle, the Ormulum, another well-known early Middle English Danelaw document, and Cursor Mundi.

\section{Sources}

The quotes in (1) and (4) are from the Dictionary of Old English at http://www .doe.utoronto.ca.ezproxy1.lib.asu.edu/pages/pub/web-corpus.html and those in (2) and (3) from the Middle English Dictionary at http://quod.lib.umich.edu .ezproxyı.lib.asu.edu/c/cme/.

\section{References}

Callaway, Morgan. 1913. The Infinitive in Anglo-Saxon. Washington: Carnegie.

Emonds, Joseph Embley and Jan Terje Faarlund. 2014. English: The Language of the Vikings. Olomouc: Palacký University Press.

Emonds, Joseph Embley and Jan Terje Faarlund. This issue. English as North Germanic: A summary.

van der Gaaf, Willem. 1933. The split infinitive in Middle English. English Studies 15: $15^{-20 .}$

van Gelderen, Elly. 1993. The Rise of Functional Categories. Amsterdam:John Benjamins. Visser, Frederik. 1972. An Historical Syntax of the English Language II. Leiden: Brill. 